\title{
Analisis dan Desain Sistem Pengambilan Keputusan Pengangkatan Karyawan Tetap di PT. Aerofood ACS
}

\author{
Rohmat Taufiq ${ }^{1}$, Rachmad Taufiq Prasetyo ${ }^{2}$, Dadang Yusuf ${ }^{3}$ \\ ${ }^{1,2}$ Teknik Informatika, Universitas Muhammadiyah Tangerang, Jalan Perintis Kemerdekaan I \\ Babakan No.33, RT.007/RW.003, Cikokol, Kec. Tangerang, Indonesia 15118 \\ ${ }^{3}$ Informatika, Fakultas Ilmu Komputer, Universitas Singaperbangsa, Karawang, Indonesia, 411361 \\ e-mail: 'rohmat.taufiq@umt.ac.id; ²ptaufiq48@gmail.com, ${ }^{3}$ dadang.dyf@ staff.unsika.ac.id
}

Submitted Date: June $07^{\text {th }}, 2020$

Revised Date: July $31^{\text {st }}$, 2020
Reviewed Date: July $28^{\text {th }}, 2020$

Accepted Date: July $31^{\text {st }}, 2020$

\begin{abstract}
Analysis and Design of the decision-making system for the appointment of permanent employees is done at PT. Aerofood ACS. The problem with appointment of permanent employees is that the selection process for permanent employees is still long, it is difficult to determine which employees should be taken if the number of qualified employees is more than needed. This research is a system analysis conducted with the aim to provide analysis and design results making it easier for management to develop into webbased applications. the method conducted in this research is by communicating with management and employees, determining problems, the process of finding data, making plans about the research to be carried out, conducting analysis followed by making a design proposal given to management, the latter being the process of making reports. The conclusion from the research carried out can find out how the process of hiring non-permanent employees to become permanent employees, giving design proposals to the management in detail so that hopes can be developed into a web-based decision support system that has the goal so that the system uses the most suitable method.
\end{abstract}

Keyword: Analysis; Design; Decision Making; Appointment; Employees

Analisis dan Desain sistem pengambilan keputusan pengangkatan karyawan tetap dilakukan di PT. Aerofood ACS. Masalah yang ada dalam pengangkatan karyawan tetap yaitu proses seleksi yang dilakukan dalam penerimaan karyawan tetap masih lama, sulit untuk menentukan karyawan mana yang harus diambil jika jumlah yang lolos lebih dari yang di butuhkan. Penelitian ini merupakan sebuah analisis sistem yang dilakukan dengan tujuan untuk memberikan hasil analisis dan desain sehingga memudahkan pihak manajemen untuk mengembangkan ke dalam aplikasi berbasis web. metede yang dilakukan dalam penelitian ini dengan cara komunikasi dengan pihak manajemen dan karyawan, menentukan masalah, proses pencarian data, membuat rencana tentang penelitian yang akan dilakukan, melakukkan analisis yang dilanjutkan dengan membuat desain usulan yang diberikan kepada pihak manajemen yang yang terakhir yaitu proses pembuatan laporan. Kesimpulan dari penelitian yang dilakukan bisa mengetahui bagaimana proses pengangkatan dari pegawai tidak tetap untuk menjadi pegawai tetap, memberikan usulan desain kepada pihak manajemen secara rinci sehingga harapannya bisa dikembangkan ke dalam sistem pendukung keputusan berbasis web yang memiiki tujuan agar sistem tersebut menggunakan metode yang paling sesuai.

Keyword: Analisis; Desain; Pengambilan Keputusan; Pengangkatan; Karyawan

\section{Pendahuluan}

Karyawan tidak tetap merupakan karyawan di mana status di tempat kerjanya berada dalam masa percobaan (probation). Dalam masa tersebut bisasanya perusahaan akan menilai kinerja karyawan tersebut baik dari sisi kualitas ataupun kuantitas. Dengan status percobaan tersebut maka akan menjadikan hak-hak karyawan menjadi lemah. Jika dalam penilaian masa percobaan tersebut dan nilai yang didapatkan karyawan di bawah harapan atau standar yang sudah ada maka karena perusahaan dapat memberhentikan 
(terminate) karyawan. Mengacu Undang-undang No. 13 Tahun 2003 Tentang Ketenagakerjaan (UU Ketenagakerjaan), paling lama masa percobaan karyawan sebanyak 3 bulan. Jika dalam masa percobaan tersebut dan karyawan mendapatkan nilai di atas standar maka pihak perusahaan bisa melakukan pengangkatan menjadi karyawan tetap. Setelah karyawan melakukan uji coba dan dinyatakan di atas standar yang ada maka muncullah pertanyaan, wajibkah perusahaan membuatkan surat keputusan khusus untuk mengangkatnya menjadi karyawan tetap? Dan ternyata jawaban dari pertanyaan tersebut adalah tergantung dari perusahaan yang sudah dituangkan dalam perjanjian kerja sama dengan karyawan tersebut.

Posisi karyawan dengan masa percobaan merupakan karyawan yang secara psikologi akan selalu tunduk pada perjanjian perjanjian kerja untuk waktu tidak tertentu (PKWTT). Dalam PKWTT, di mana sebuah perusahaan dan karyawan akan saling membutuhkan untuk bekerjasama dalam hubungan kerja jangka panjang (tanpa batas waktu).

Ada perbedaan yang mencolok antara PKWTT dengan PKWT yaitu jika PKWT perjanjian dilakukan secara lisan atau tidak dibuat secara tertulis. Maka dari itu pengangkatan karyawan untuk menjadi karyawan tetap harus dilakukan dengan menggunakan surat pengangkatan secara tertulis. Jika ditinjau lagi dalam Pasal 63 Ayat (1) UU Ketenagakerjaan: "perjanjian dalam waktu tertentu yang tidak tertulis maka perusahaan memiliki kewajiban untuk memberikan surat pengangkatan bagi calon karyawan". Ini sudah menjadi risiko buat jaminan pegawai dan menjadi sesuatu yang wajib bagi perusahaan.

Masalah yang ada dalam pengangkatan karyawan tetap yaitu proses seleksi yang dilakukan dalam penerimaan karyawan tetap masih lama, sulit untuk menentukan karyawan mana yang harus diambil jika jumlah yang lolos lebih dari yang dibutuhkan, karena belum ada bobot per kriteria dan laporan karyawan belum bisa akurat, relevan, tepat waktu dan lengkap

\section{Landasan Teori}

Menurut Spradley (Sugiyono, 2015) mengatakan bahwa analisis merupakan suatu aktivitas yang dilakukan dengan tujuan mencari pola selain itu suatu cara berfikir yang berhubungan dengan pengujian secara sistematis terhadap sesuatu untuk menentukan bagian, hubungan antar bagian dan hubungannya dengan keseluruhan. Sedangkan dalam ahli yang lain menyatakan bahwa analisis sistem merupakan suatu cara yang dilakukan untuk mengidentifikasi penyebabnya, memberikan solusi buat sistem dari hasil identifikasi yang sudah dilakukan (Loudon dan Loudon, 2012). Sedangkan menurut Jeffery (2004) analisis sistem adalah sebuah itilah yang secara kolektif menjelaskan langkah-langkah awal dalam pengembangan sistem. Dengan demikian sudah barang tentu ada desain sistem di dalam analisis sistem (Taufiq, dkk, 2019).

Sistem Pendukung Keputusan (SPK) merupakan sebuah pendekatan yang sistematis terhadap suatu masalah, pengumpulan data secara matang serta menentukan alternatif yang sesuai dengan kasus serta proses pengambilan keputusan secara tepat. Menurut Suryadi dalam Taufiq (2018). Sistem pendukung keputusan penentuan karyawan terbaik dengan metode profile matching dapat membantu dalam proses menentukan suatu keputudsan dan menghasilkan siapa karyawan terbaik dengan tepat (Abidin, 2017).

Penelitian yang berhubungan dengan sistem pendukung keputusan juga pernah dilakukan oleh Taufiq (2015) yang digunakan dalam proses penilaian kinerja dosen sehingga ketemu kriteriakriteria yang bermanfaat buat instansi. Selain itu penerapan sistem pendukung keputususan dengan lebih rinci yaitu menggunakan metode Analytical Hieararcny Process (AHP) dinilai dapat mempermudah proses kenaikan pangkat dalam hal pembutan laporan dan penentuan kenaikan pangkat (Suherdi, dkk 2018).

Status karyawan dibagi menjadi 2 yaitu karyawan tetap dan karyawan kontrak. Karyawan tetap adalah karyawan yang mendapakan pendapatan sesuai dengan ketentuan yang sudah disepakati secara teratur, sedangkan karyawan tidak tetap merupakan karyawan yang bekerja berdasarkan kontrak yang sudah disepakati untuk suatu jangka waktu tertentu sepanjang pegawai yang bersangkutan bekerja penuh (full time) dalam pekerjaan tersebut (Edianto, 2015).

Mengacu pada Undang-Undang Nomor 13 tahun 2003 menjelaskan ketentuan yang berlaku bagi karyawan tetap ataupun kontrak sebagai berikut: A. Tidak ditentukan batasan dalam jangka waktu lamaanya bekerja, B. Hubungan kerja antara perusahaan dan karyawan kontrak ditulis dalam "Perjanjian Kerja Untuk Waktu Tidak Tertentu", C. Perusahaan dapat mensyaratkan masa percobaan maksimal 3 bulan, D. Masa kerja dihitung sejak masa percobaan, E. Jika terjadi pemutusan 
hubungan kerja bukan karena pelanggaran berat atau karyawan mengundurkan diri maka karyawan tetap mendapatkan uang pesangon, uang penghargaan masa kerja (bagi karyawan yang bekerja minimal 3 tahun) dan uang penggantian hak sesuai UU yang berlaku (UU, 2003)

\section{Metodologi Penelitian}

Dalam penelitian ini terdapat 5 langkah yang dilakukan (Gambar 1), di mana langkah pertama dimulai dari komunikasi dengan pihak peruahaan dilanjutkan dengan menentukan permasalahan yang ada, untuk langkah ketiga pencarian data yang dibutuhkan dan diikutidengan membuat rencana penelitian. Setelah rencana dibuat langkah selanjutnya melakukan analisis dan diikuti dengan membuat desain. Dalam langkah pembuatan desain metode yang digunakan yaitu dengan Unifeid Modeling Language (UML) sedangkan langkah terakhir yaitu membuat laporan akhir yang diguankan sebagai hasil akhir dari penelitian ini.

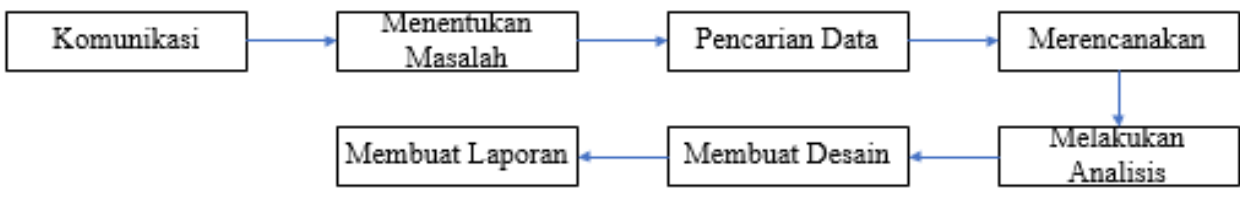

Gambar 1 Metode Penelitian

Dengan tujuh langkah yang dilakukan dalam penelitian ini bisa menghasilkan sebuah desain dan laporan yang sesuai dengan apa diharapkan.

\section{Hasil dan Pembahasan}

\subsection{Gambaran Sistem yang Berjalan Prosedur pengangkatan Pegawai Tetap}

Prosedur pengangkatan status tenaga kerja outcourcing menjadi calon karyawan tetap sebagai berikut:

1. Pembentukan tim untuk mensukseskan proses pengangkatan karyawan tetap

2. Mengusulkan nama kepada Manajemen

3. Seleksi kriteria sebagai karyawan tetap

4. Keikutsertaan tenaga outcourcing dalam tes kompetensi standar SOP tenaga kerja di sektor bandara internasional soekarno hatta

5. Penetapan nomor identitas pegawai dalam pengangkatan karyawan baru

6. Pengangkatan karyawan outcourcing menjadi karyawan tetap dimulai dari proses penyerahan SK

\section{Kriteria yang harus dipenuhi}

Persyaratan tenaga kerja outcourcing untuk diangkat menjadi karyawan tetap menurut kriteria Aerofood ACS:

1. Penilaian karawan kontrak

Head department melakukan penilaian evaluasi karyawan kontrak yang akan habis masa kerjanya.

2. F4S (forum satu, saya, sapa, salut)

Karyawan kontrak yang diajukan untuk menjadi karywan tetap, wajib terlebih dahulu mengikuti ajang f4s minimal sampai dengan level unit.

3. Mandatory dan functional Training

Karyawan kontrak yang diajukan untuk menjadi karyawan tetap, terlebih dahulu harus mengikuti mandatory dan functional training serta lulus dalam post test yang diselenggarakan.

4. Test tertulis

Karyawan kontrak mengikuti test tertulis dengan jadwal yang telah ditentukan oleh human capital dengan standar kelulusan minimal 9.0.

5. Psikotes

Karyawan kontrak mengikuti psikotes dengan jadwal dan tempat yang telah ditentukan oleh human capital serta lulus sesuai dengan standar yang telah ditentukan.

6. Medical check up

Karyawan kontrak mengikuti medical check up dengan jadwal dan tempat yang telah ditentukan oleh human capital serta dinyatakan sehat oleh dokter rumah sakit.

7. Pengangkatan karyawan tetap

Karyawan yang telah mengikuti dan lulus dalam serangkaian proses pengangkatan karyawan tetap akan diproses dan menerima SK pengangkatan karyawan tetap.

\subsection{Pembahasan}

\subsubsection{Pembuatan Use Case}




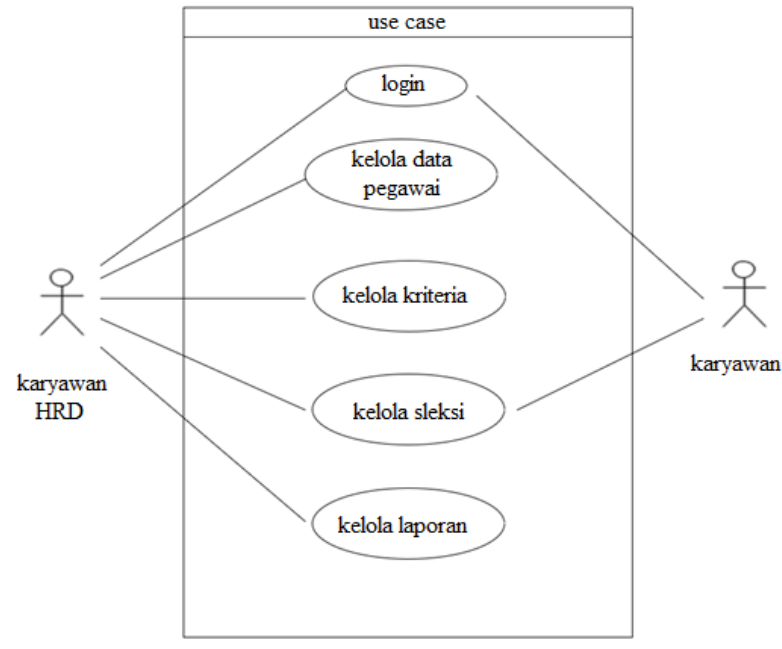

Gambar 2 Use Case Pengangkatan Karyawan Tetap

Use case pada Gambar 2 di atas menjelaskan bahwa sistem secara umum memiliki 2 tipe user yaitu: HRD dan Karyawan. HRD memiliki fungsi untuk mengelola data pegawai, mengelola data kriteria, kelola seleksi dan kelola laporan. Sedangkan karyawan hanya untuk mengikuti seleksi

\subsubsection{Activity Diagram}

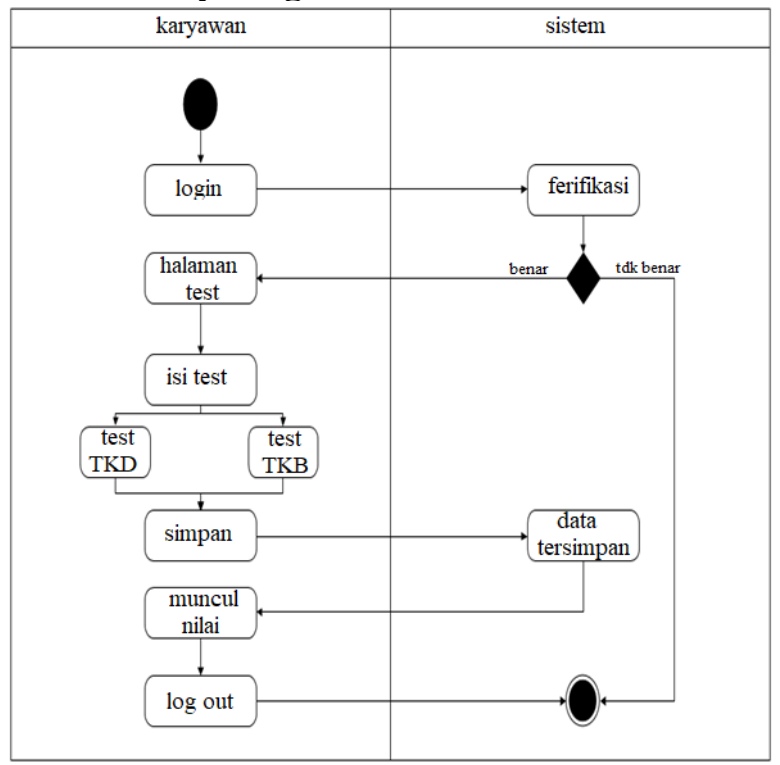

Gambar 3 Activity Diagram kelola Kriteria
Gambar 3 menjelaskan bagaimana kegiatan yang dilakukan oleh karyawan pada saat megikuti seleksi. Yang dilakukan pada saat mengikuti seleksi yaitu melakukan login, mengisi soal TKD, mengisi soal TKB maka nilai akan otomatis muncul dan selesai.

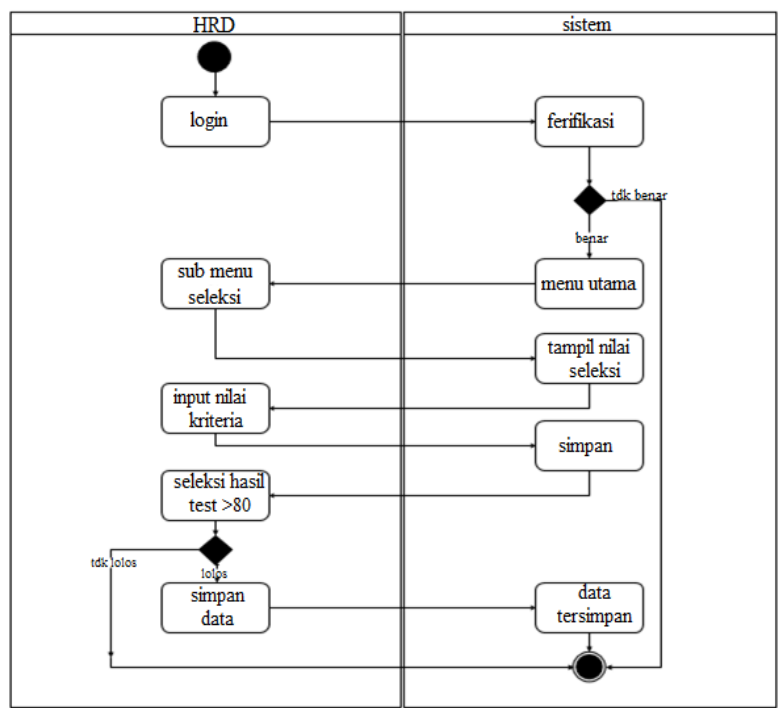

Gambar 4 Acitivity Diagram Seleksi

Pada Gambar 4 menjelaskan kegiatan atau aktivitas yang dilakukan oleh HRD dalam melakukan seleksi karyawannya. Secara umum melakukan input nilai seleksi dan nilai kriteria, setelah itu dilakukan maka otomatis nilai akan muncul dan keterangan lulus atau gagal juga akan secara otomatis muncul.

\subsubsection{Sequence Diagram}

Pada Gambar 5, sequence diagram seleksi karyawan menjelaskan bagaimana seorang karyawan berhubungan dengan sistem untuk melakukan proses seleksi. Karyawan melakukan login terlebih dahulu setelah itu mengisi naskah soal TKD dan TKB dan selanjutnya klik tombol simpan. Setelah disimpan secara otomatis akan muncul nilai yang didapatkan. 


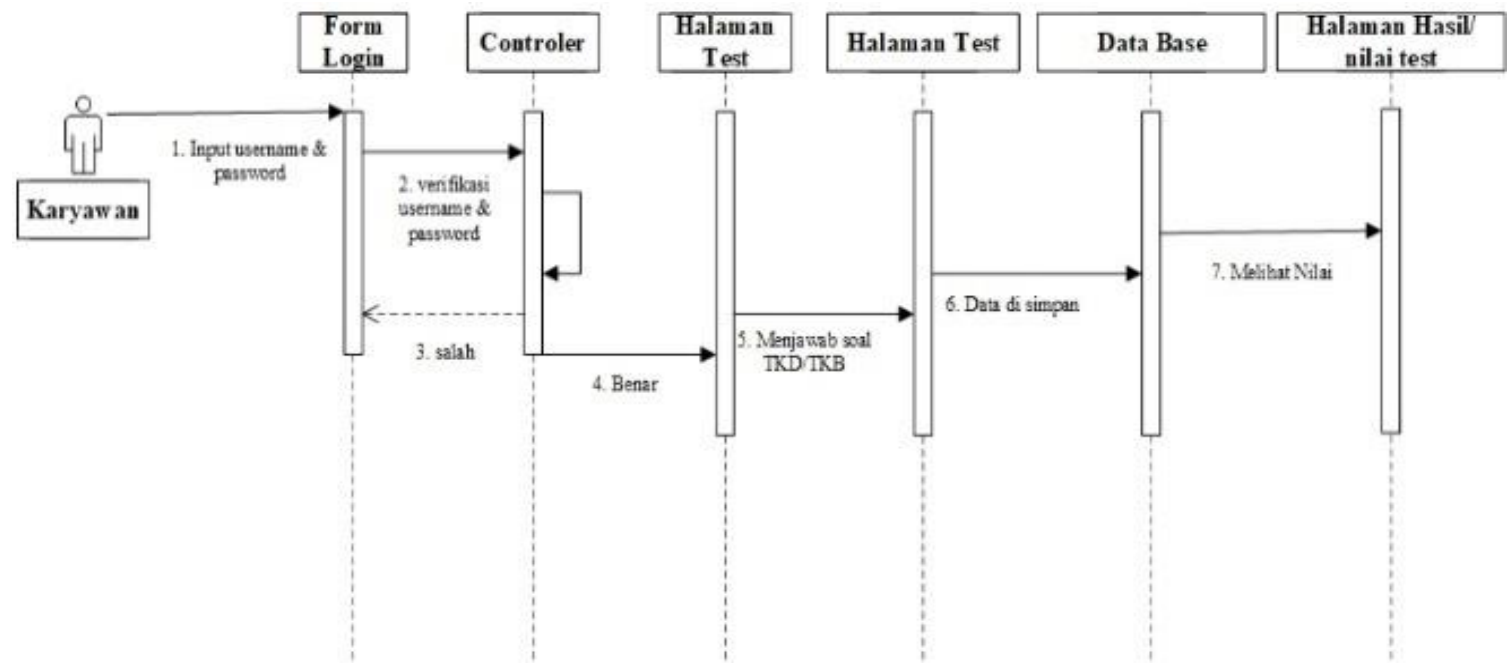

Gambar 5 Sequence Seleksi Karyawan

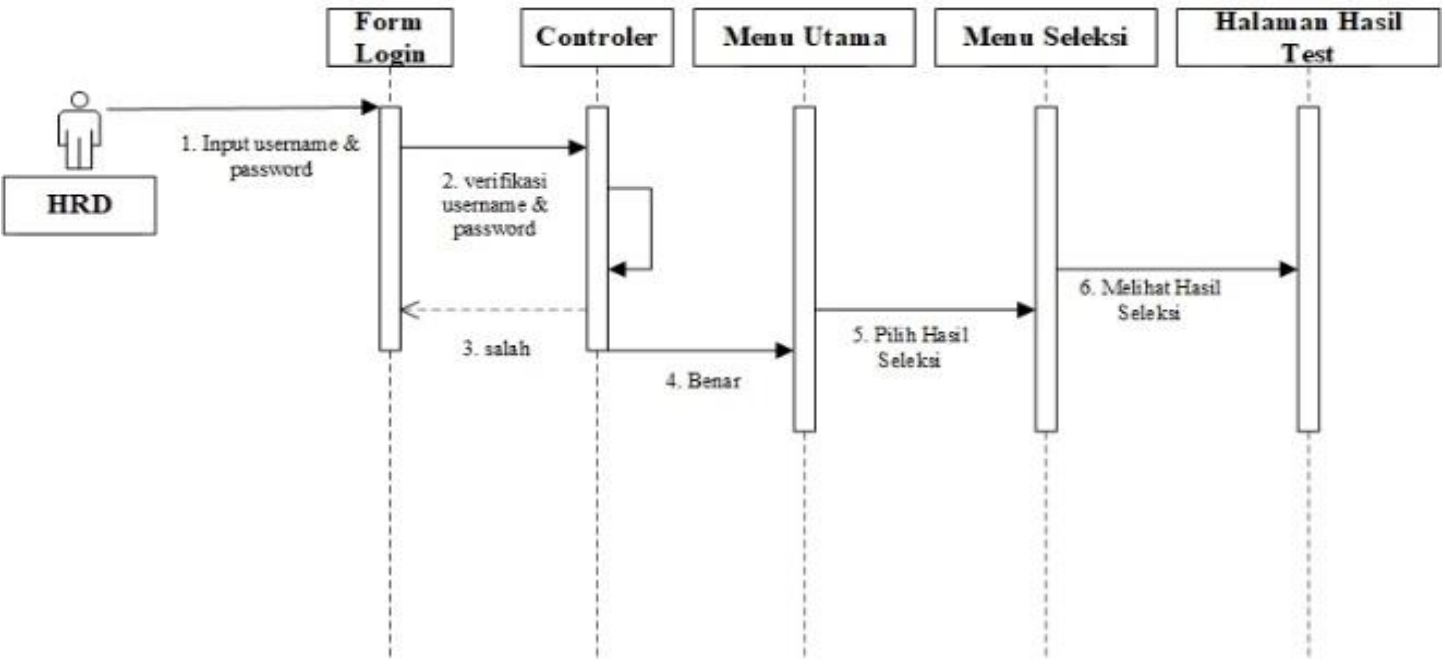

Gambar 6 Squence Seleksi oleh HRD

Sequence seleksi oleh HRD pada Gambar 6 menjelaskan bagaimana seorang HRD melakukan penilaian kepada karyawannya. Penilaian dimulai dari login selanjutnya masuk menu utama yang dialnjutkan lagi pada menu seleksi. Setelah memasukkan nilai hasil tes dan nilai kriteria yang lain klik simpan maka akan muncul hasil yang menyatakan karyawan tersebut lulus atau gagal.

\subsubsection{Desain Login}

Gambar 7 (Login) menjelaskan bagaimana seorang user akan masuk ke sistem yang diusulkan. Setelah memasukkan user nama dan password, dan jika sesuai dengan database maka akan masuk ke sistem namun jika tidak sesuai maka tidak akan masuk.

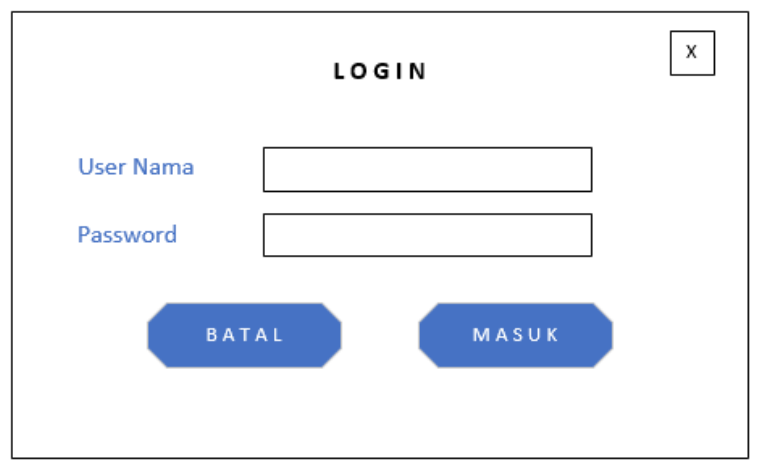

Gambar 7 Desain Login 


\subsubsection{Desain Seleksi Karyawan}

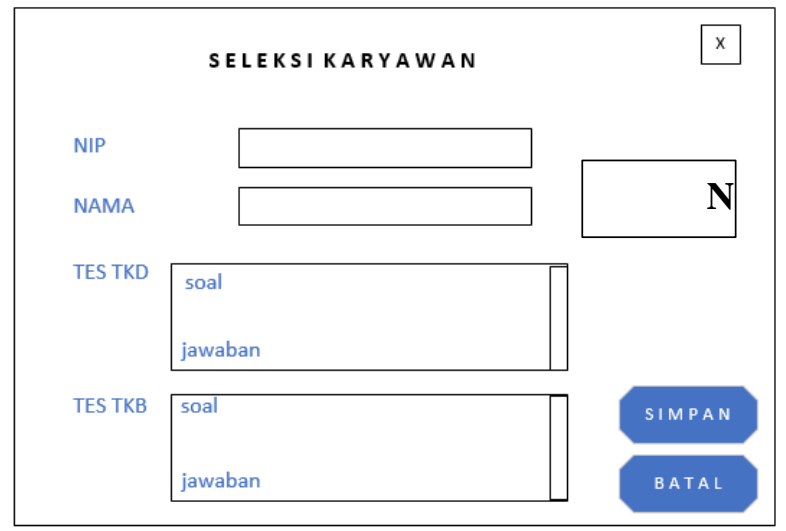

Gambar 8 Desain Seleksi Karyawan

Desain seleksi karyawan pada Gambar 8 diisi oleh masing-masing karyawan yang sudah terpilih, maka akan diberikan kesempatan untuk mengikuit tes tersebut. Dalam tes tersebut terdapat dua soal yaitu TKD dan TKB. Setelah mengisi soal yang sudah ada maka pilih tombol simpan setelah disimpan nilai otomatis akan muncul.

\subsubsection{Desain Seleksi HRD}

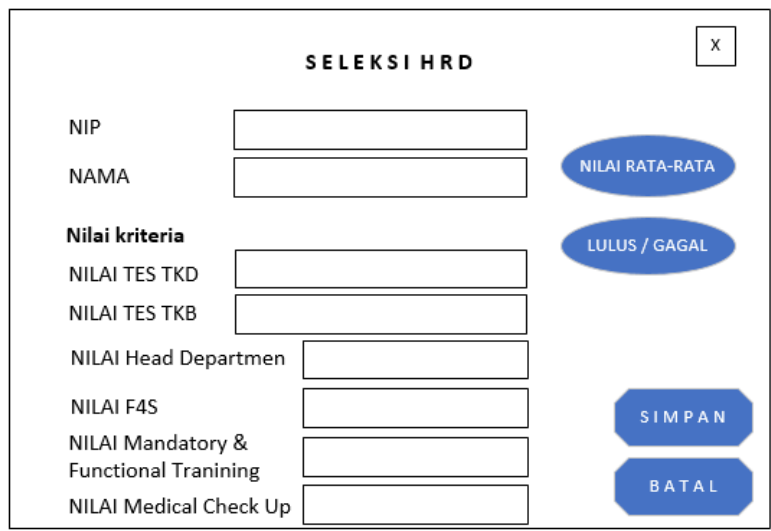

Gambar 9 Desain Seleksi HRD

Dalam Gambar 9 di atas yang menjelaskan tentang seleksi yang dilakukan oleh HRD, HRD melakukan seleksi dari 6 kriteria. Kriteria tersebut terdiri dari beberapa langkah: nilai tes TKD, nilai tes TKB, Nilai head department, Nilai F4S (forum satu, saya, sapa, salut), Nilai Mandatory \& Functional Tranining dan yang terakhir Nilai Medical Check Up.

\subsubsection{Desain Laporan}

Dalam laporan hasil seleksi pada Gambar 10 memberikan informasi Nip, Nama, Hasil Tes Tkd,
Hasil Tes Tkb, Nilai Dari Head Departement, Nilai F4s, Nilai Mandatory \& Functional Tranining, Hasil Medical Check Up dan yang Terakhir Keterangan Lulus Atau Gagal. Laporan di atas juga bisa dilihat berdasarkan hari, tanggal, bulan, tahun dan jam berapa. Harapannya laporan bisa dilihat secara real time bahkan pada seleksi terakhir sudah dilakukan maka nilai sudah bisa dilihat oleh direktur nya melalui web.

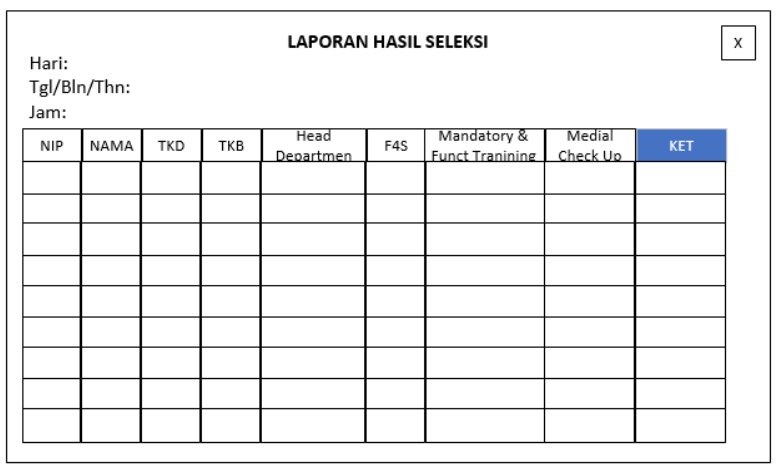

Gambar 10 Laoran Hasil Seleksi

\section{Kesimpulan}

Sistem pendukung keputusan pengangkatan karyawan tetap merupakan salah satu metode yang digunakan untuk melakukan pengangkatan dari pegawai tidak tetap ke pegawai tetap. Sistem ini bersifat dinamis terhadap kriteria dan bobot preferensi dalam pengambilan keputusan sehingga kriteria dan bobot preferensi dapat diubah sesuai dengan ketentuan yang berlaku. Pengembangan yang dilakukan dalam penelitian ini adalah dengan memasukkan prioritas yang digunakan untuk 90 perhitungan terhadap nilai total calon karyawan tetap terhadap pilihan HRD.

\section{Penelitian Selanjutnya}

Peneliti selanjutnya yang bisa dilakukan yaitu merancang sebuah sistem pendukung keputusan bebasis web dengan menggunakan metode yang tepat dengan mengambil analisis dan desain yang sudah dilakukan ini.

\section{Referensi}

Abidin, Z. K. (2017). Penerapan Metode Profile Matching Dalam Sistem Pendukung Keputusan Penentuan Karyawan terbaik pada PT. Ananda Solusindo Cikarang. Program Studi Teknik Informatika STIMIK-STBA Nusa Mandiri.

Edianto, B. (2015). Sistem Pendukung Keputusan Pengangkatan Karyawan Tetap dengan metode Analytic Hierarchy Process (AHP) 
Pada PT. Perkebunan Lembah Bhakti Provinsi NAD Kab. Aceh Singkil”, Jurnal Pelita Informatika Budi Dharma, ISSN: 2301-9425, Volume: IX, Nomor: 3, April 2015: 96-10

Loudon, K.C. and Laudon, J.P. (2012). Manajemen Information System: Managing The Digital Firm. 12Th Edition: Prentice-Hall.

Sugiyono. (2015). Metode Penelitian Kombinasi (Mix Methods). Bandung: Alfabeta

Suherdi, R.A, Taufiq, R. Yanuardi, Permana, A.A. (2018). Penerapan Metode AHP dalam Sistem Pendukung Keputusan Kenaikan Pangkat Pegawai Di Badan Kepegawaian Dan Pengembagan Sumber Daya Manusia Kota Tangerang. in SINTAK, 2018, pp. 522-528.

Taufiq, R. (2015). Penilaian Kinerja Dosen Dalam Bidang Belajar Mengajar Di Fakultas Teknik
Universitas Muhammadiyah Tangerang. Jurnal Faktor Exacta Vol. 5 No. 1: 77-85 ISSN: 1979 276X.

Taufiq, R. Maelani, N dan Liesnaningsih (2019). Analisis dan Desain Sistem Penerimaan Karyawan Baru Pada PT. Surya Toto Indonesia. Jurnal Teknik Informatika (JIKA) Universias Muhammadiyah Tangerang. Februari 2019. ISSN: 2519-0710. Hal 67-74.

Taufiq, R. Permana, AA, Cahyoanto, T dan Adha, R (2018). Sistem Pendukung Keputusan Penerimaan Karyawan Menggunakan Simple Additive Weighting Studi Kasus PT. Trafoindo Prima Perkasa. Jurnal Al-Azhar Indonesia Seri Sains dan Teknologi, Vol. 4 No. 4. September 2018. Hal. 186-194.

Undang-Undang No. 13 Tahun (2003) Tentang Ketenagakerjaan 